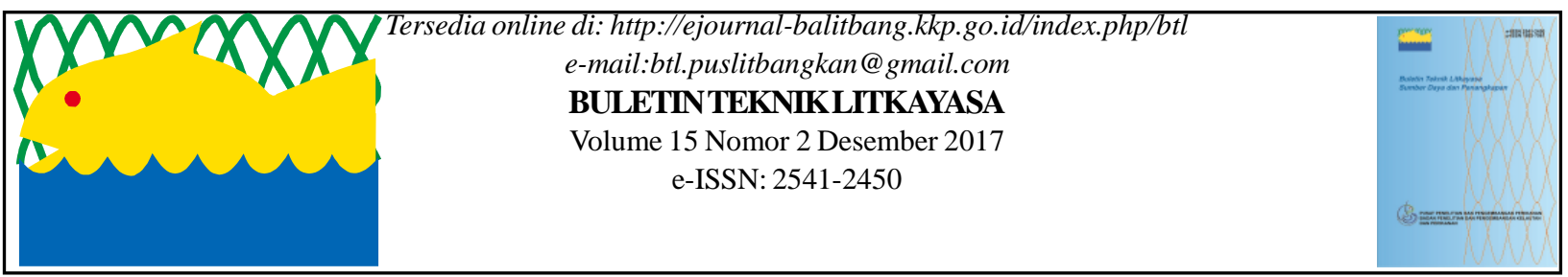

\title{
HUBUNGAN TOTAL PADATAN TERLARUT DAN KONDUKTIVITAS PERAIRAN DI DANAU LIMBOTO, PROVINSI GORONTALO
}

\author{
Dedi Sumarno, Tri Muryanto dan Sumindar \\ Teknisi Litkayasa Balai Penelitian Pemulihan dan Konservasi Sumber Daya Ikan \\ Teregistrasi I tanggal: 30 November 2017; Diterima setelah perbaikan tanggal: 08 Desember 2017; \\ Disetujui terbit tanggal: 13 Desember 2017
}

\section{PENDAHULUAN}

Total Padatan Terlarut atau Total Dissolved Solids (TDS) adalah terlarutnya zat padat, baik berupa ion, berupa senyawa, koloid di dalam air (Nicola, 2015). TDS biasanya disebabkan oleh bahan anorganik yang berupa ion-ion yang biasa ditemukan di perairan (Effendi, 2003). Menurut Slamet (1994), bila total zat padat terlarut bertambah maka kesadahan pada perairan akan naik pula.

Konduktivitas adalah gambaran numerik dari kemampuan air untuk meneruskan aliran listrik (Effendi, 2003). Arus listrik di dalam larutan dihantarkan oleh ion yang terkandung di dalamnya. Ion memiliki karakteristik tersendiri dalam menghantarkan arus listrik. Menurut Irwan dan Afdal (2016), banyaknya ion di dalam larutan juga dipengaruhi oleh padatan terlarut di dalamnya. Semakin besar jumlah padatan terlarut di dalam larutan maka kemungkinan jumlah ion dalam larutan juga akan semakin besar, sehingga nilai konduktivitas juga akan semakin besar.

Danau Limboto berdasarkan kriteria Kementerian Lingkungan Hidup termasuk perairan Danau di Indonesia yang digolongkan kritis karena sedimentasi dan eutrofikasi (Krismono, 2014). Danau ini di kelilingi lima kecamatan yaitu, Kecamatan Limboto, Telaga, Telaga Biru, Batudaa, dan Kecamatan Kota Barat. Danau Limboto bermuara lima sungai yang berhulu di Kabupaten Gorontalo yaitu Sungai Molopu, Sungai Alu, Sungai Daenaa, Sungai Bionga dan Sungai Molalahu. Outlet Limboto adalah Danau Sungai
Tapodu yang muaranya di Sungai Bolango yang akhirnya bermuara ke laut (Balihristi, 2007).

Danau Limboto mempunyai manfaat sebagai sumber air, penahan banjir, irigasi pertanian dan perikanan. Kegiatan perikanan yang ada berupa perikanan tangkap dan budidaya. Saat ini, Danau Limboto mengalami degradasi berupa pengurangan luasan dan pendangkalan oleh sedimentasi yang dibawa oleh air yang berasal dari daerah hulu (sungaisungai yang menuju Danau). Dampak degradasi Danau Limboto adalah sering terjadinya banjir pada saat hujan di beberapa wilayah yang berdekatan dengan Danau, semakin luasnya daratan dan penurunan produksi ikan budidaya dalam keramba jaring tancap. Tujuan dari penelitian ini adalah untuk mengetahui hubungan antara TDS dengan konduktivitas di Danau Limboto.

\section{POKOK BAHASAN \\ Bahan Dan Metode \\ Lokasi dan Waktu Penelitian}

Penelitian dilakukan pada Februari, Juli, dan Oktober 2016 di 7 stasiun pengamatan, yaitu: Dembe, Tabumela (area penangkapan ikan), Inlet Danau Limboto, Kayu Bulan, Payunga, Tengah Danau, lluta (area Keramba jaring tancap) (Gambar 1 dan Tabel 1).

\section{Alat dan Bahan}

Alat dan bahan yang digunakan untuk mengukur nilai TDS dan konduktivitas di Danau Limboto Provinsi Gorontalo adalah sebagai berikut (Tabel 2): 


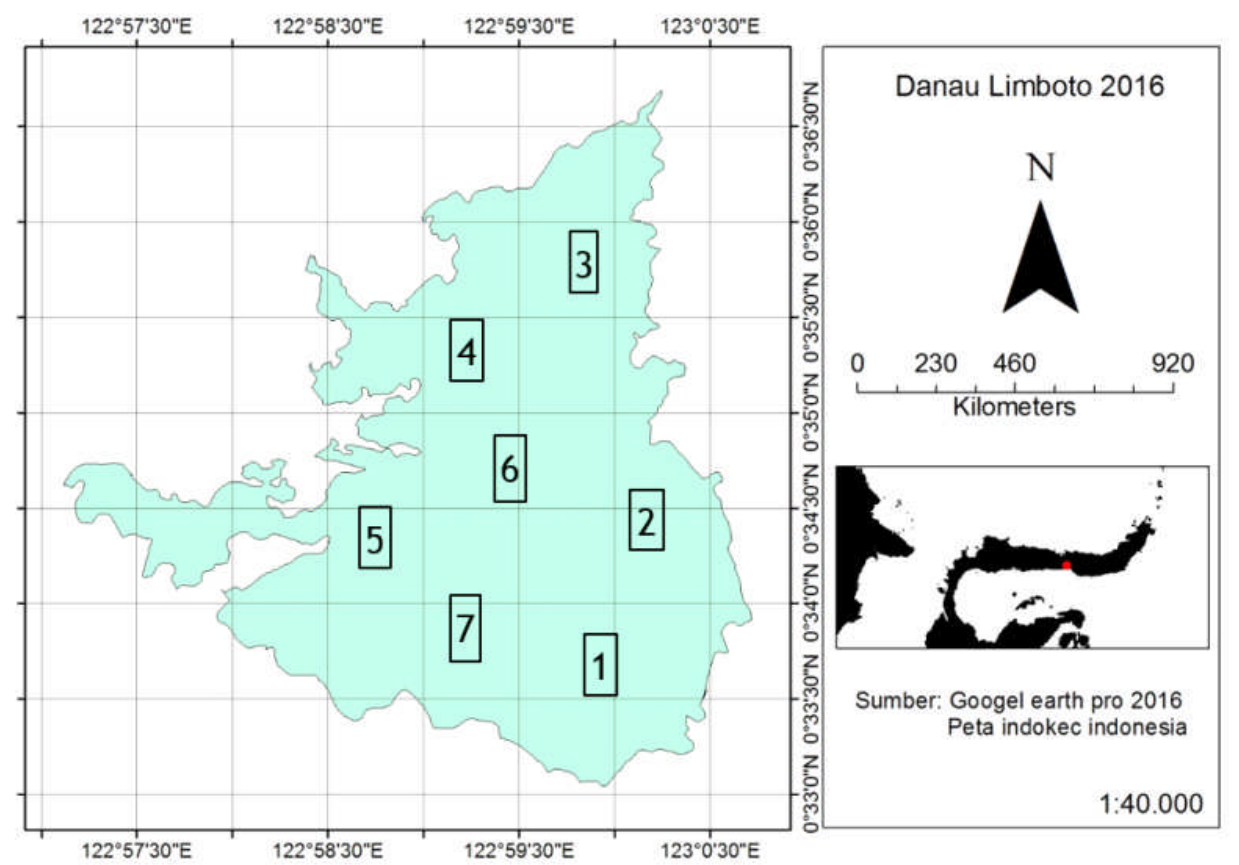

Gambar 1. Peta lokasi pengukuran TDS dan konduktivitas di Danau Limboto 2016.

Tabel 1. Koordinat lokasi Penelitian Di Danau Limboto

\begin{tabular}{clc}
\hline No. & \multicolumn{1}{c}{ Nama Stasiun Pengamatan } & \multicolumn{1}{c}{ Koordinat } \\
\hline 1 & Dembe & $00^{\circ} 33,320^{\prime} \mathrm{N} ; 123^{\circ} 00,072^{\prime} \mathrm{E}$ \\
2 & Area Tabumela (penangkapan) & $00^{\circ} 34,398^{\prime} \mathrm{N} ; 122^{\circ} 59,899^{\prime} \mathrm{E}$ \\
3 & Inlet Danau Limboto & $00^{\circ} 35,716^{\prime} \mathrm{N} ; 122^{\circ} 59,660^{\prime} \mathrm{E}$ \\
4 & Kayu Bulan & $00^{\circ} 35,053^{\prime} \mathrm{N} ; 122^{\circ} 58,963^{\prime} \mathrm{E}$ \\
5 & Payunga & $00^{\circ} 34,263^{\prime} \mathrm{N} ; 122^{\circ} 58,301^{\prime} \mathrm{E}$ \\
6 & Tengah Danau & $00^{\circ} 34,495^{\prime} \mathrm{N} ; 122^{\circ} 59,515^{\prime} \mathrm{E}$ \\
7 & Karamba Jaring lluta Tancap & $00^{\circ} 33,682^{\prime} \mathrm{N} ; 122^{\circ} 59,327^{\prime} \mathrm{E}$ \\
\hline
\end{tabular}

Tabel 2. Alat dan bahan yang digunakan pada pengukuran TDS dan konduktivitas

\begin{tabular}{cll}
\hline No. & \multicolumn{1}{c}{ Alat dan Bahan } & \multicolumn{1}{c}{ Fungsi / Kegunaan } \\
\hline 1 & Wqc YSI & Mengukur TDS dan konduktivitas \\
2 & Perahu kayu & Alat transportasi menuju stasiun \\
3 & Blanko Pengamatan & pengamatan \\
4 & Aquades & Mencatat hasil pengukuran \\
5 & Blanko Pengamatan & Membersihkan probe wqc \\
6 & Tissue & Mencatat hasil pengukuran \\
\end{tabular}

\section{Metode}

Prosedur Pengukuran TDS dan Konduktivitas dengan wqc YSI

1. Wqc YSI dinyalakan dengan menekan tombol "power" dan didiamkan selama 5 menit untuk menstabilkan alat

2. Pelindung probe dilepas dan probe dimasukkan ke dalam badan air pada kedalaman $50 \mathrm{~cm}$ dari permukaan air atau tergantung tingkat kedalaman air

3. Didiamkan probe pada kedalaman tersebut hingga alat menunjukkan nilai TDS dan konduktivitas yang stabil

4. Dicatat nilai TDS dan konduktivitas dalam blanko pengamatan

5. Setelah digunakan probe dicuci dengan menggunakan aquades 


\section{Pelaksanaan Pengukuran di Lapangan (Insitu)}

Pengukuran nilai TDS dan konduktivitas dilakukan dengan menggunakan alat waterquality checker (wqc) YSI pada kedalaman $50 \mathrm{~cm}$ dari permukaan perairan. hasil pengukuran TDS dan konduktivitas dilakukan perhitungan koefisen korelasi untuk mengetahui pola hubungan antara nilai TDS dan konduktivitas di Danau Limboto.

\section{Perhitungan Koefisien Korelasi}

Perhitungan koefisien korelasi antara TDS dan konduktivitas di perairan Danau Limboto dilakukan dengan menggunakan rumus sebagai berikut (Riduwan, 2003):

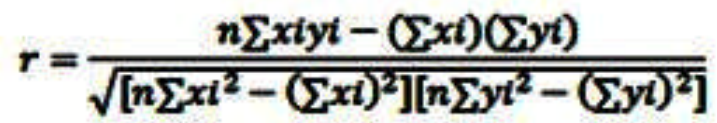

Keterangan :

xi : variabel nilai konduktivitas $(\mu \mathrm{S} / \mathrm{cm})$

yi : variabel nilai TDS (mg/l)

Kriteria nilai $r$ (Riduwan, 2003) sebagai berikut:

- $0,00-0,199$ : korelasi sangat lemah

- $0,20-0,399$ : korelasi lemah

- 0,40-0,599: korelasi cukup

- $0,60-0,799$ : korelasi kuat

- $0,80-1,000$ : korelasi sangat kuat

\section{Hasil}

Nilai TDS dan konduktivitas pada 7 stasiun pengamatan di Danau Limboto pada Februari, April, Juli dan Oktober 2016, secara terinci di sajikan pada Tabel 3.

Tabel 3. Nilai TDS dan konduktivitas di Danau Limboto tahun 2016

\begin{tabular}{|c|c|c|c|}
\hline Waktu & Nama Stasiun & TDS (mg/l) & $\begin{array}{l}\text { Konduktivitas } \\
(\mu \mathrm{S} / \mathrm{cm})\end{array}$ \\
\hline \multirow{7}{*}{ Februari 2016} & Dembe & 383.50 & 634.00 \\
\hline & Area Tabumela (penangkapan) & 377.00 & 632.00 \\
\hline & Inlet Danau Limboto & 390.00 & 679.00 \\
\hline & Kayu Bulan & 390.00 & 674.00 \\
\hline & Payunga & 383.50 & 645.00 \\
\hline & Tengah Danau & 387.50 & 660.00 \\
\hline & Iluta (KJT) & 377.00 & 666.00 \\
\hline \multirow{7}{*}{ April 2016} & Dembe & 422.50 & 680.00 \\
\hline & Area Tabumela (penangkapan) & 429.00 & 738.00 \\
\hline & Inlet Danau Limboto & 429.00 & 730.00 \\
\hline & Kayu Bulan & 474.50 & 805.00 \\
\hline & Payunga & 416.00 & 706.00 \\
\hline & Tengah Danau & 422.50 & 715.00 \\
\hline & Iluta (KJT) & 422.50 & 722.00 \\
\hline \multirow{7}{*}{ Juli 2016} & Dembe & 207.35 & 345.00 \\
\hline & Area Tabumela (penangkapan) & 208.00 & 352.00 \\
\hline & Inlet Danau Limboto & 234.65 & 403.00 \\
\hline & Kayu Bulan & 209.00 & 355.00 \\
\hline & Payunga & 204.10 & 343.00 \\
\hline & Tengah Danau & 206.05 & 349.00 \\
\hline & Iluta (KJT) & 205.40 & 346.00 \\
\hline \multirow{9}{*}{ Oktober 2016} & Dembe & 245.70 & 400.50 \\
\hline & Area Tabumela (penangkapan) & 239.70 & 412.00 \\
\hline & Inlet Danau Limboto & 261.95 & 455.40 \\
\hline & Kayu Bulan & 227.50 & 386.50 \\
\hline & Payunga & 213.20 & 379.60 \\
\hline & Tengah Danau & 225.85 & 385.60 \\
\hline & Iluta (KJT) & 214.00 & 388.10 \\
\hline & Min & 204.10 & 343.00 \\
\hline & Max & 474.50 & 805.00 \\
\hline
\end{tabular}


Tabel 3, menunjukkan bahwa nilai TDS dan konduktivitas pada Februari, April, Juli dan Oktober 2016 masing-masing berkisar antara $204.10-474,50$ $\mathrm{mg} / \mathrm{l}$ dan $343.00-805.00 \mu \mathrm{S} / \mathrm{cm}$. Nilai TDS dan konduktivitas tertinggi terjadi pada bulan April di stasiun Kayu Bulan, diduga karena April merupakan musim kemarau. Nilai TDS dan konduktivitas terendah terjadi pada Juli di stasiun Payunga, diduga karena Juli sudah memasuki musim hujan.
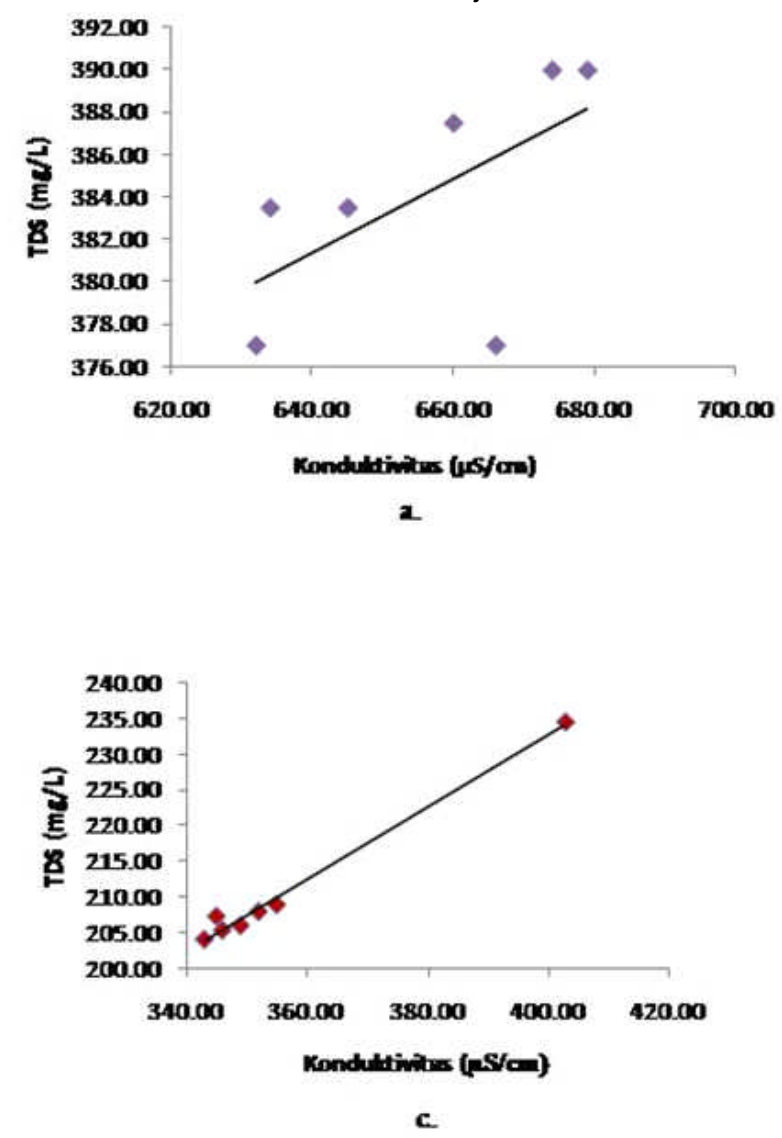

Gambar 3. Hubungan TDS dengan konduktivitas di Danau Limboto tahun 2016 (a. bulan Februari, b. bulan April, c. bulan Juli dan d. bulan Oktober).

Koefisien korelasi ( $r$ ) berdasarkan nilai TDS dan konduktivitas di Danau Limboto pada bulan Februari, April, Juli dan Oktober 2016 masing-masing sebesar $0.5978,0.9190,0.9942$ dan 0.8959 . Nilai koefisien korelasi pada Februari 2016 termasuk dalam kriteria korelasi cukup ( $r: 0.40-0.599)$ antara nilai TDS dan konduktivitas di perairan Danau Limboto. Nilai koefisien korelasi pada bulan April, Juli dan Oktober 2016 termasuk dalam kriteria korelasi yang sangat kuat ( $r: 0.80-1.000$ ) antara nilai TDS dan konduktivitas di perairan Danau Limboto.

\section{KESIMPULAN}

Nilai TDS dan konduktivitas di perairan Danau Limboto, 2016 masing-masing berkisar antara 204.10 $-474.50 \mathrm{mg} / \mathrm{l}$ dan $343.00-805.00 \mu \mathrm{S} / \mathrm{cm}$. Nilai TDS
Gambar 3. menunjukkan bahwa adanya hubungan yang linier antara nilai konduktivitas dengan TDS, semakin besar pula nilai TDSnya. Namun pada (gambar 3a) terjadi pola cenderung linear, hal ini diduga karena adanya faktor tidak ketelitian dalam pembacaan alat wqc dan performance alat pada saat pengukuran.
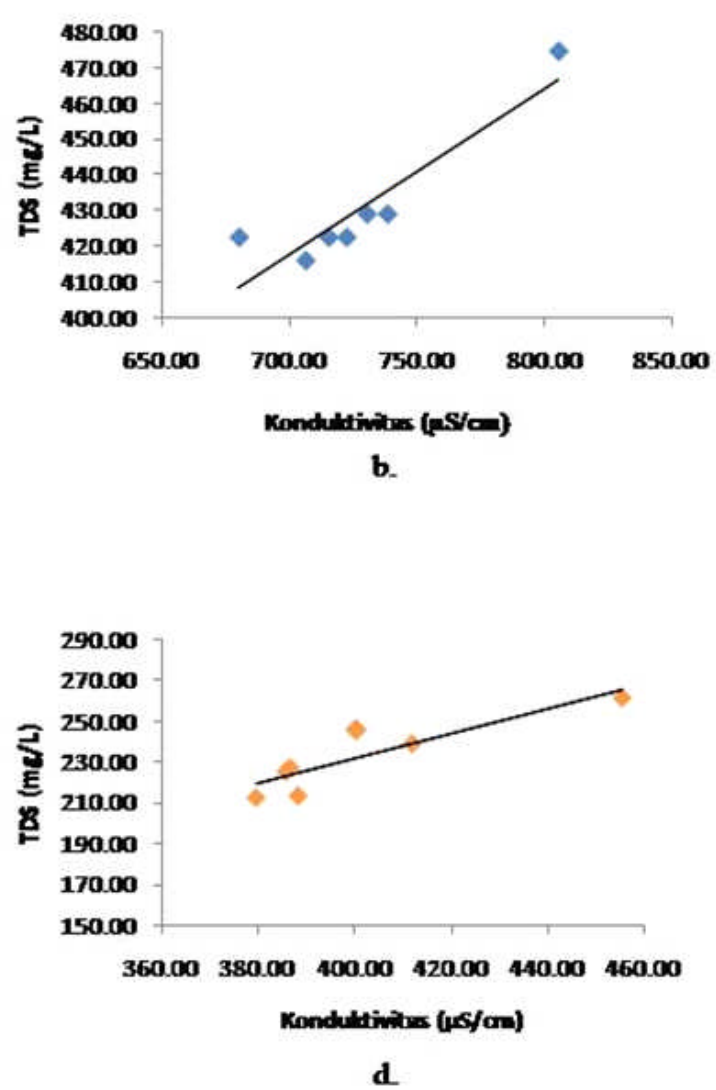

dan konduktivitas hasil pengukuran di perairan Danau Limboto 2016 menunjukkan hubungan yang linear. Koefisien korelasi pada bulan Februari termasuk kriteria korelasi cukup, dan kriteria korelasi yang sangat kuat terjadi pada April, Juli dan Oktober 2016.

\section{PERSANTUNAN}

Tulisan ini merupakan bagian dari kegiatan penelitian "Pemulihan Habitat dan Konservasi Sumberdaya Danau Limboto" dengan sumber dana APBN 2016 di Balai Riset Pemulihan Sumber Daya Ikan. Penulis mengucapkan terimakasih kepada Prof. Dr. Krismono, M.S yang telah mengijinkan menggunakan data TDS dan Konduktivitas untuk penulisan makalah ini. Penulis mengucapkan terimakasih kepada Prof. Dr. Krismono, MS sebagai dimana semakin besar nilai konduktivitas maka 
penanggung jawab kegiatan penelitian yang telah memberi ijin menggunakan sebagian datanya.

\section{DAFTAR PUSTAKA}

Anonimus. (2007). Status lingkungan hidup daerah Provinsi Gorontalo. Badan Lingkungan Hidup, Riset dan Teknologi Informasi. Pemerintah Provinsi Gorontalo.

Effendi, H. (2003). Telaah kualitas air (p. 59 - 61). Bagi Pengelolaan Sumber Daya dan Lingkungan Perairan. Kanisius. Yogyakarta.

Irwan, F. \& Afdal. (2016). Analisis hubungan konduktivitas listrik dengan total dissolved solid (TDS) dan Temperatur pada Beberapa Jenis Air. Jurnal Fisika Unand. 5(1), 86 - 93. Universitas Andalas. Padang. Sumatera Barat.
Krismono. (2014). Danau Limboto: Peluang Pemanfaatan. LIPI Press. Jakarta. Hal.xv

Nicola, F. (2015). Hubungan antara konduktivitas, TDS (Total Dissolved Solid) dan TSS (Total Suspended Solid) dengan Kadar Fe2+ dan Fe Total Pada Air Sumur Gali. Jurusan Kimia Fakultas Matematika dan Ilmu Pengetahuan Alam Universitas Jember. JawaTimur. Hal. 7

Riduwan. (2003). Skala pengukuran variabel-variabel penelitian. Alfabeta. Bandung.

Slamet, J. S. (1994). Kesehatan lingkungan. Gadjah Mada University Press. Yogyakarta. 